\section{Nitrogen Use Efficiency and Onion Yield Increased with a Polymer-coated Nitrogen Source}

\author{
Dan Drost ${ }^{1}$ and Rich Koenig \\ Department of Plants, Soils, and Biometeorology, Utah State University, \\ Logan, UT 84322-4820 \\ Terry Tindall \\ JR Simplot Company, P.O. Box 912, Pocatello, ID 83204
}

Additional index words. Allium cepa, controlled-release fertilizer, $\mathrm{N}$ use efficiency

\begin{abstract}
Nitrogen (N) losses can be substantial in furrow-irrigated onions (Allium cepa $\mathrm{L}$.). Polymer-coated urea (PU) may reduce $\mathrm{N}$ losses and result in an increase in productivity. In this study, we investigated the effects of different rates and blends of urea and PU on onion yield and $\mathrm{N}$ use for two cropping seasons. Nitrogen was applied at 112, 168, and 224 $\mathrm{kg} \cdot \mathrm{ha}^{-1}$ as PU or urea. In addition, three PU/urea blends equal to $224 \mathrm{~kg} \cdot \mathrm{ha}^{-1}$ of $\mathrm{N}$ were compared. Plant growth and $\mathrm{N}$ concentration, soil nitrate concentrations, and bulb yield

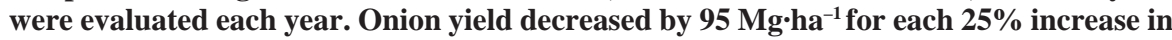
the proportion of urea in the fertilizer blends. Reducing the $\mathbf{N}$ rates from 224 to 112 $\mathrm{kg} \cdot \mathrm{ha}^{-1}$ had minimal effect on bulb yield when all the fertilizer was supplied by urea. A reduction of $\mathrm{N}$ applied from 224 to $168 \mathrm{~kg} \cdot \mathrm{ha}^{-1}$ had little effect on yield, although a further reduction to $112 \mathrm{~kg}^{\circ} \mathrm{ha}^{-1}$ did significantly reduce bulb yield when the entire $\mathrm{N}$ was supplied from PU. Nitrogen source and rate had no effect on bulb maturity and only minor effects on leaf area and storage potential. Soil sampling indicated that more $\mathrm{N}$ was retained in PUtreated onion beds than in urea-treated beds, which improved nitrogen use efficiency. In addition, $\mathbf{N}$ use efficiency improved when there was more $\mathrm{PU}$ in the blend and when PU was compared with urea at the same rate. We conclude that the use of PU can dramatically improve $\mathrm{N}$ use efficiency and productivity in direct-seeded onions.
\end{abstract}

Bulb development in onions is primarily promoted by long photoperiods and high temperatures (Brewster, 1994). Nitrogen (N) also plays an important role in this process primarily by controlling leaf growth. Early applications of N can hasten (Riekels, 1977), or have little effect on (Brewster, 1994) crop maturity while low $\mathrm{N}$ levels can delay maturity (Henriksen, 1987). Late-season applications of $\mathrm{N}$ or high residual $\mathrm{N}$ concentrations in the soil often delay or prevent bulbing under marginal photoperiods but have no influence when photoperiods are ideal (Scully et al., 1945). Excessive $\mathrm{N}$ applications have also increased leaf blade growth late in the season (Brewster, 1994), which delays crop maturity (Schwartz and Bartolo, 1995) and contributes to increased storage losses (Brewster, 1994; Brown et al., 1988).

Onion $\mathrm{N}$ application rates in Utah vary from 224 to $>392 \mathrm{~kg} \cdot \mathrm{ha}^{-1}$ (Drost et al., 1997). These rates are substantially higher than the 168 to $280 \mathrm{~kg} \cdot \mathrm{ha}^{-1}$ recommended by the Univ.

Received for publication 16Feb. 2001. Accepted for publication 22 June 2001. This project was supported in part by the JR Simplot Company, Pocatello, Idaho. Approved as Utah Agricultural Experiment Station Journal no. 7370. The willingness of Morgan Reeder of Mountain View Acres and Blake Norman of Norman Farms to use their commercial onion fields is greatly appreciated.

${ }^{1}$ To whom reprint requests should be addressed. Phone: 435-797-2258; fax: 435-797-3376; e-mail address: dand@ext.usu.edu of Idaho (Brown, 2000), Oregon State Univ. (Mansour et al., 1983), or Colorado State Univ. (Schwartz and Bartolo, 1995). Growers tend to overapply $\mathrm{N}$ to compensate for losses due to excessive irrigation applications or from anxiety that yields will be less than needed to maintain profitability. When high $\mathrm{N}$ applications are combined with excessive irrigation, nitrate leaching can occur (Drost et al., 1997; Ells et al., 1993; Feibert et al., 1993). Leaching of $\mathrm{NO}_{3}-\mathrm{N}$ ultimately leads to its movement into groundwater, posing a threat to the quality of the water resource. Therefore, using $\mathrm{N}$ fertilizer sources that are less prone to leaching (controlled-release $\mathrm{N}$ ) or timing $\mathrm{N}$ applications (multiple applications) with plant growth stage are possible ways of minimizing $\mathrm{N}$ loss.

Controlled-release $\mathrm{N}$ fertilizers are often used to reduce $\mathrm{N}$ leaching losses from soils (Wang and Alva, 1996) and to extend $\mathrm{N}$ availability through a growing season (Wiedenfeld, 1986). Sulfur-coated urea has often been used as a slow-release $\mathrm{N}$ form for a variety of vegetables (Guertal, 2000; Wiedenfeld, 1986), including onion (Brown et al., 1988; Wiedenfeld, 1986). With a single application of controlled-release $\mathrm{N}$, yield is generally equal to or greater than that obtained with multiple applications of $\mathrm{N}$ from soluble $\mathrm{N}$ forms like urea.

The disadvantage of most controlled-release $\mathrm{N}$ forms is that their release properties are controlled by the solubility of the coating material, environmental conditions (tempera- ture, moisture), microbial decomposition, and diffusion of the $\mathrm{N}$ through the coating (Hauck, 1985; Kochba et al., 1990). These properties are affected by soil temperature and moisture and may mean that release rates do not coincide with a plant's $\mathrm{N}$ demand. In contrast, the mechanism of $\mathrm{N}$ release from polymer-coated $\mathrm{N}$ sources is by water movement across the membrane, dissolution of the $\mathrm{N}$ core, and osmotic transport of $\mathrm{N}$ back across the membrane (Hummell, 1989), thus creating a controlled-release formulation. In addition to being influenced by temperature and moisture (Hummell, 1989; Wang and Alva, 1996), these processes are also strongly influenced by the polymer coating. Modifying the polymer coating can produce different release rate characteristics. A coating resulting in initial controlled-release of $\mathrm{N}$ early in the season and more rapid release as soil temperatures increase would overcome some of the disadvantages of traditional slow-release materials. Single, early-season application of a correctly timed controlled-release $\mathrm{N}$ source to onion would simplify farm fertilizer practices, could improve yields and $\mathrm{N}$ use efficiency, and reduce $\mathrm{N}$ leaching. The objective of this study was to assess the effects of early-season application of a polymer-coated $\mathrm{N}$ source on growth, yield, bulb quality, and $\mathrm{N}$ use efficiency of onion compared with a non-coated urea $\mathrm{N}$ fertilizer. The specific polymer-coated $\mathrm{N}$ source, Polyon 43, developed by RCL Industries (Sylacauga, Ala.), has a 90-d release window, which should meet the $\mathrm{N}$ needs of direct-seeded onions.

\section{Materials and Methods}

Sweet Spanish onions 'Tesoro' and 'Vision' were direct-seeded on 25 Mar. 1998 and 15 Mar. 1999 in Forsgren (fine, montmorillonitic, mesic Vertic Argixerolls) and Fridlo (fine-silty, mixed, mesic Typic Natrixerolls) silt loam soils, respectively. The experimental design was a randomized complete block with nine $\mathrm{N}$ treatments and four replications. Treatments were applied to six onion beds, each 7.6 $\mathrm{m}$ long. Plots were arranged down the rows across the length of the field each year. Bed configurations varied slightly according to the individual grower's practice with onions seeded at 345,000 (70-cm centers) and 454,000 (90-cm centers) seeds/ha in 1998 and 1999 . respectively.

Standard grower production practices for nutrients, irrigation, and pest and weed control were followed. Prior to bed formation in the fall, each grower applied some $\mathrm{N}$ and any additional nutrients according to soil test results. Soils used in the tests contained from $1.8 \%$ to $2 \%$ organic matter, between 80 and $100 \mathrm{mg} \cdot \mathrm{kg}^{-1}$ of organic N, had P levels of 15 to $25 \mathrm{mg} \cdot \mathrm{kg}^{-1}, \mathrm{~K}$ levels of 250 to $350 \mathrm{mg} \cdot \mathrm{kg}^{-1}$, and $\mathrm{pH}$ ranging from 7.6 to 7.9. Growers applied $\mathrm{P}$ [from monoammonium phosphate (MAP)] at 70 to $80 \mathrm{~kg} \cdot \mathrm{ha}^{-1}, \mathrm{~K}$ (from sulfate of potash) at 30 to $40 \mathrm{~kg} \cdot \mathrm{ha}^{-1}$, sulfur (from sulfate of potash) at 8 to $10 \mathrm{~kg} \cdot \mathrm{ha}^{-1}$, and zinc at 5 to $6 \mathrm{~kg} \cdot \mathrm{ha}^{-1}$. In 1998 , only the $40 \mathrm{~kg} \cdot \mathrm{ha}^{-1} \mathrm{~N}$ from MAP was applied in the fall. However, in 1999, an addi- 
tional $100 \mathrm{~kg} \cdot \mathrm{ha}^{-1} \mathrm{~N}$ as urea was applied to hasten the decomposition of wheat stubble. All other $\mathrm{N}$ was applied as treatments in the spring. Polymer-coated urea $(43 \% \mathrm{~N})$ or urea $(46 \% \mathrm{~N})$ separately or as blends were applied to plots on 27 May 1998 and 28 May 1999 with an applicator calibrated to deliver the required $\mathrm{N}$ amounts. For those treatments that received both the polymer-coated urea (PU) and urea-N $(\mathrm{U})$, the materials were delivered separately to ensure that the correct amount was applied. The $\mathrm{N}$ was banded into the shoulder of the bed $7.6 \mathrm{~cm}$ from the row and $7.6 \mathrm{~cm}$ deep when onions were in the three- to four-leaf stage.

Plant growth and $\mathrm{N}$ status were evaluated throughout each growing season. Stand counts were made 2 weeks after the $\mathrm{N}$ applications. Ten plants from each treatment were collected monthly and used to assess growth. Leaf area was determined with an automatic analyzer (CI-203 area meter; CID, Inc., Camas, Wash.). Individual area values were multiplied by two and summed over the number of leaves per plant to calculate total leaf area. Plants were then dried at $70{ }^{\circ} \mathrm{C}$, weighed, ground, and analyzed for $\mathrm{N}$ concentration by combustion (model CHN-1000; Leco Corp., St. Joseph, Mich.). Soil N status was assessed before the initial $\mathrm{N}$ application in May. Analysis of the initial soil samples indicated the soil contained 12 and $175 \mathrm{~kg} \cdot \mathrm{ha}^{-1}$ of residual nitratenitrogen in the surface $30 \mathrm{~cm}$ of soil in 1998 and 1999, respectively. The bulk of this $\mathrm{N}$ came from applications made by the grower the previous fall and mineralized $\mathrm{N}$ from soil organic matter. Additional soil samples were collected at 0 - to 30- and 30- to 60-cm depths in the middle of the beds at monthly intervals during 1999. In early Aug. 1999, beds from one replication of the 100PU and 100U treatments were sampled in cross-section by collecting separate cores at $0-15,15-30,30-45$, and $45-60 \mathrm{~cm}$ depths at five equally spaced intervals across the bed. The transect began in the center of the furrow on one side of the bed and continued in $25-\mathrm{cm}$ increments to the center of the furrow on the opposite side of the bed. Based on this initial cross-section, beds from the first three replications of five selected treatments (100PU or $100 \mathrm{U}$ at 112 and 224 $\mathrm{kg} \cdot \mathrm{ha}^{-1} \mathrm{~N}$ and 50PU-50U at $224 \mathrm{~kg} \cdot \mathrm{ha}^{-1} \mathrm{~N}$ ) were sampled in cross-section on 24 Aug. 1999. All soil samples were extracted with $0.12 \mathrm{~m}$ ammonium sulfate and analyzed for nitrate-nitrogen $\left(\mathrm{NO}_{3}-\mathrm{N}\right)$ with ion-selective electrodes. Nitrate-nitrogen values were converted to kilograms of $\mathrm{N}$ per hectare by assuming a soil bulk density of $1.30 \mathrm{~g} \cdot \mathrm{cm}^{-3}$ and multiplying the $\mathrm{NO}_{3}-\mathrm{N}$ concentration in each 15 -cm-depth increment by a factor of 2 . An N budget was calculated by adding the $\mathrm{N}$ recovered from the plant tissue and the soil. Nitrogen not accounted for was assumed to be leached below the root zone or lost via volatilization. Nitrogen uptake (NUPE), utilization (NUTE), and $\mathrm{N}$ use efficiency (NUE) were calculated from biomass, tissue $\mathrm{N}$ concentration, and plant population each year.

Onion maturity was assessed twice weekly beginning in mid-August to determine loss of plant vigor and time when $50 \%$ of plants had leaves that had fallen over (50\% top-down). At maturity, onion bulbs were mechanically lifted, field-cured for $5 \mathrm{~d}$, then hand-topped before removal from the field. Bagged onions were cured for an additional $10 \mathrm{~d}$ before assessing bulb size and weight. Onion bulbs were graded into culls (rots, diseased, splits, $<5.7 \mathrm{~cm}$ diameter bulbs), medium $(5.7-7.6 \mathrm{~cm})$, jumbo $(7.6$ $10.2 \mathrm{~cm})$, and colossal $(>10.2 \mathrm{~cm})$ grades before counting and weighing the samples. Yield comparisons taken from the grower's field adjacent to the test site were $78 \mathrm{Mg} \cdot \mathrm{ha}^{-1}$ in 1998 and $82 \mathrm{Mg} \cdot \mathrm{ha}^{-1}$ in 1999 , respectively. The bulbs were placed in a commercial storage facility until early January and then reevaluated for storage potential (weight loss, rotting, sprouting, breakdown).

Data were analyzed using the GLM and regression procedures of SAS (SAS Institute, Cary, N.C.) for each year. Single-degree-offreedom contrasts were used to evaluate the effects of the $\mathrm{N}$ treatments on growth, yield, and quality. In addition, mean separation was achieved by least significant difference (LSD) at the $\alpha=0.05$ level. Regression analysis was performed where appropriate.

\section{Results and Discussion}

Yield. Nitrogen source and rate significantly affected onion bulb yield (Fig. 1). As the percentage of urea in the mix increased, total yield decreased linearly $[\mathrm{y}=95.6-5.3 \times$ (\% urea); $\left.r^{2}=0.92\right]$ when $\mathrm{N}$ was supplied at the $224 \mathrm{~kg} \cdot \mathrm{ha}^{-1}$ application rate. Yield increases associated with PU were due mainly to an increase in colossal and jumbo bulbs (Fig. 1, Table 1). Increasing the proportion of urea in the mix resulted in fewer jumbo and colossal onions but had little effect on medium bulbs. Planned contrasts support these findings and illustrate that, for the same rate of $\mathrm{N}$ applied, supplying that $\mathrm{N}$ as PU rather than urea increased total and large bulb-size classes (Table 2 ). Since bulb numbers harvested were not different between treatments (data not shown), excessive $\mathrm{N}$ losses or poor $\mathrm{N}$ use efficiency may be responsible for the lower yields in

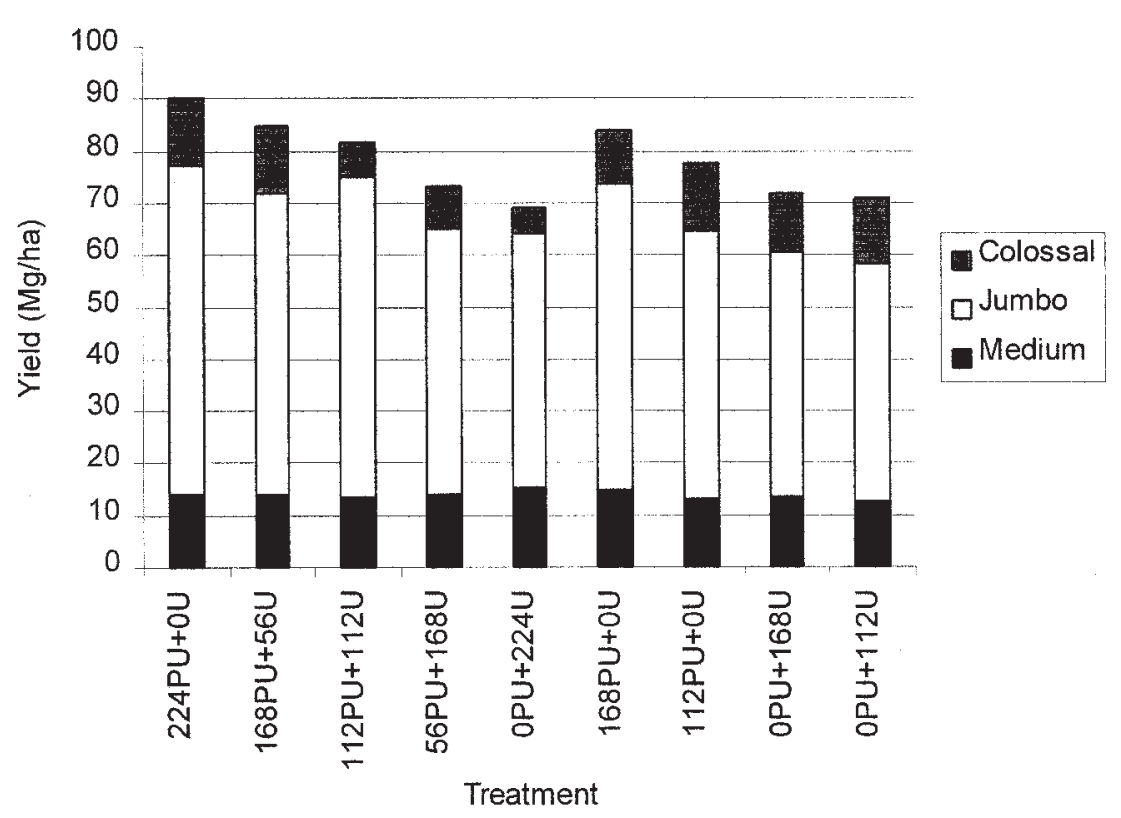

Fig. 1. Effects of rates of urea (U) and polymer-coated urea (PU) on onion bulb yield (colossal, jumbo, medium). Values are the mean of both years. Refer to Table 1 for treatment codes.

Table 1. Effect of rates of urea (U) and polymer-coated urea (PU) on colossal, jumbo, and medium onion yields in 1998 and 1999. Treatments equal to the total amount of nitrogen supplied from the different nitrogen sources.

\begin{tabular}{|c|c|c|c|c|c|c|c|c|}
\hline \multirow{3}{*}{$\begin{array}{l}\text { Treatment } \\
\left(\mathrm{kg} \cdot \mathrm{ha}^{-1} \mathrm{~N}\right)\end{array}$} & \multicolumn{8}{|c|}{ Yield $\left(\mathrm{Mg} \cdot \mathrm{ha}^{-1}\right)$} \\
\hline & \multicolumn{2}{|c|}{ Colossal } & \multicolumn{2}{|c|}{ Jumbo } & \multicolumn{2}{|c|}{ Medium } & \multicolumn{2}{|c|}{ Total } \\
\hline & 1998 & 1999 & 1998 & 1999 & 1998 & 1999 & 1998 & 1999 \\
\hline $224 \mathrm{PU}+0 \mathrm{U}$ & 22.1 & 3.6 & 55.4 & 71.2 & 5.2 & 22.5 & 82.7 & 97.3 \\
\hline $168 \mathrm{PU}+56 \mathrm{U}$ & 23.5 & 2.8 & 51.6 & 63.7 & 4.1 & 23.7 & 79.2 & 90.2 \\
\hline $112 \mathrm{PU}+112 \mathrm{U}$ & 8.8 & 4.8 & 61.8 & 61.0 & 6.7 & 20.5 & 77.3 & 86.3 \\
\hline $56 \mathrm{PU}+168 \mathrm{U}$ & 14.8 & 1.8 & 51.1 & 50.5 & 7.2 & 21.0 & 73.1 & 73.3 \\
\hline $0 \mathrm{PU}+224 \mathrm{U}$ & 10.2 & 0 & 46.8 & 51.1 & 7.5 & 22.8 & 64.5 & 73.9 \\
\hline $168 \mathrm{PU}+0 \mathrm{U}$ & 18.5 & 2.6 & 58.0 & 58.9 & 5.0 & 25.0 & 81.5 & 86.5 \\
\hline $0 \mathrm{PU}+168 \mathrm{U}$ & 19.0 & 3.0 & 47.0 & 51.0 & 4.9 & 21.7 & 70.9 & 75.7 \\
\hline $112 \mathrm{PU}+0 \mathrm{U}$ & 23.6 & 2.6 & 42.4 & 60.3 & 5.9 & 20.5 & 71.9 & 83.4 \\
\hline $0 \mathrm{PU}+112 \mathrm{U}$ & 23.0 & 1.8 & 43.4 & 44.8 & 3.0 & 21.7 & 69.4 & 68.3 \\
\hline $\mathrm{LSD}_{0.05}$ & 9.2 & 5.7 & 9.7 & 11.1 & 4.0 & 8.6 & 10.2 & 5.5 \\
\hline \multicolumn{9}{|c|}{ Mean yield across treatments } \\
\hline Year & 18.1 & 2.6 & 50.8 & 57.4 & 5.5 & 22.2 & 74.4 & 82.2 \\
\hline
\end{tabular}


those treatments with more urea in the mix. This observation is consistent with Brown et al. (1988).

Reducing the rate of $\mathrm{N}$ applied from 224 to $168 \mathrm{~kg} \cdot \mathrm{ha}^{-1}$ had no effect on yield when the $\mathrm{N}$ was supplied by PU alone, although a further reduction to $112 \mathrm{~kg} \cdot \mathrm{ha}^{-1} \mathrm{~N}$ did significantly lower yields (Fig. 1). Yield was weakly correlated with increasing $\mathrm{N}$ rates when $\mathrm{N}$ was supplied by PU alone $[\mathrm{y}=66.3+0.12 \times(\mathrm{PU}$ rate); $r^{2}=0.23$ ]. Our findings are in agreement with reports showing onions can be grown with $\mathrm{N}$ at $168 \mathrm{~kg} \cdot \mathrm{ha}^{-1}$ (Brown, 2000; Drost et al., 1997; Mansour et al., 1983; Schwartz and Bartolo, 1995). Brown et al. (1988) and Wiedenfeld (1986) also noted onion yield reductions when less than recommended rates of $\mathrm{N}$ were supplied as sulfur-coated urea. Use of the $168 \mathrm{PU} \mathrm{N}$ rate by onion producers should not reduce onion productivity but could reduce $\mathrm{N}$ losses, save time and labor, and improve $\mathrm{N}$ use efficiency compared with single or multiple applications of water-soluble $\mathrm{N}$ sources. When $\mathrm{N}$ was supplied by urea alone, decreasing the rate of applied $\mathrm{N}$ from 224 to $112 \mathrm{~kg} \cdot \mathrm{ha}^{-1}$ had little or no effect on yield [Fig. $1, \mathrm{y}=57.3-0.09 \times(\mathrm{U}$ rate $\left.) ; r^{2}=0.01\right]$. When evaluating the effects of the different $\mathrm{N}$ sources at the same rate (224PU vs. 224U; $168 \mathrm{PU}$ vs. $168 \mathrm{U} ; 112 \mathrm{PU}$ vs. $112 \mathrm{U}$ ), total yields were always greater when $\mathrm{N}$ was supplied from $\mathrm{PU}$ rather than urea (Table 2). Brown et al. (1988) reported similar results, particularly when $\mathrm{N}$ applications were less than recommended.

There were significant annual differences in onion productivity when assessed by singledegree-of-freedom contrasts (Table 1). Yields in the urea-only treatments were comparable with those measured in the field adjacent to these studies where $\mathrm{N}$ was applied in split applications during the season. The average yields were 75 and $85 \mathrm{Mg} \cdot \mathrm{ha}^{-1}$ in 1998 and 1999, respectively, which were not different from each other and were similar to yields collected from the grower's field. Growers regularly apply small rates of $\mathrm{N}$ during the season to maintain acceptable growth and yield. However, microbial immobilization, leaching, runoff, volatilization, and denitrification may result in yield reduction associated when all or some of the $\mathrm{N}$ is supplied as urea. There were significant differences in the yield of medium, jumbo, and colossal bulbs between years (Table 1). Differences in bed configuration and plant population were responsible for the increase in colossal yield in 1998 and medium bulbs in 1999. Since climate, cultivars, and cultural practices influence productivity, annual differences in yield often occur (Brewster, 1994; Brown et al., 1988; Wiedenfeld, 1986).

Nitrogen source and rate had no effect on bulb maturity (50\% top-down) or percent usable bulbs at harvest in either year (Table 3). After 3 months storage, there were only small differences in weight loss between the different $\mathrm{N}$ treatments. Production season did significantly impact storage potential. Weight losses were generally greater in 1998 than in 1999 (Table 3). In 1999, increasing the percentage of PU in the fertilizer blend appeared

Table 2. Orthogonal contrasts for medium, jumbo, colossal, and total onion yields as affected by rates of urea (U) and polymer-coated urea (PU). Results expressed are the average of the 2 years.

\begin{tabular}{|c|c|c|c|c|}
\hline Contrasts & Medium & Jumbo & Colossal & Total \\
\hline $224 \mathrm{~kg} \cdot \mathrm{ha}^{-1} \mathrm{~N}$ vs. rest & NS & *** & $*$ & S \\
\hline 224PU and $224 \mathrm{U}$ vs. blends & NS & NS & NS & NS \\
\hline 224PU vs. $224 \mathrm{U}$ & NS & $* *$ & $* *$ & $* *$ \\
\hline $168 / 56$ blends vs. $112 / 112$ blend & NS & $* *$ & NS & NS \\
\hline $168 \mathrm{PU}+56 \mathrm{U}$ vs. $56 \mathrm{PU}+168 \mathrm{U}$ & NS & * & s & $* *$ \\
\hline $168 \mathrm{PU}$ and $168 \mathrm{U}$ vs. $112 \mathrm{PU}$ and $112 \mathrm{U}$ & NS & $*$ & NS & NS \\
\hline 168PU vs. $168 \mathrm{U}$ & NS & $*$ & NS & $* *$ \\
\hline 112PU vs. $112 \mathrm{U}$ & NS & S & NS & $* *$ \\
\hline
\end{tabular}

Ns, s, ${ }^{*}, * *$ Nonsignificant or significant at $P=0.1,0.05$, and 0.01 , respectively.

Table 3. Effect of rates of urea (U) and polymer-coated urea (PU) on crop maturity (50\% top-down), percent usable bulbs at harvest, and percent weight loss after storage in 1998 and 1999. Treatments equal to the total amount of nitrogen supplied from the different nitrogen sources.

\begin{tabular}{|c|c|c|c|c|c|c|}
\hline \multirow{2}{*}{$\begin{array}{l}\text { Treatment } \\
\left(\mathrm{kg} \cdot \mathrm{ha}^{-1} \mathrm{~N}\right)\end{array}$} & \multicolumn{2}{|c|}{ Maturity date } & \multicolumn{2}{|c|}{$\begin{array}{c}\% \text { Usable bulbs } \\
\text { at harvest }\end{array}$} & \multicolumn{2}{|c|}{$\begin{array}{c}\text { Storage wt } \\
\text { loss }(\%)\end{array}$} \\
\hline & 1998 & 1999 & 1998 & 1999 & 1998 & 1999 \\
\hline $224 \mathrm{PU}+0 \mathrm{U}$ & 3 Sept. & 2 Sept. & 98 & 98 & 22 & 5 \\
\hline $168 \mathrm{PU}+56 \mathrm{U}$ & 3 Sept. & 7 Sept. & 100 & 97 & 16 & 11 \\
\hline $112 \mathrm{PU}+112 \mathrm{U}$ & 3 Sept. & 2 Sept. & 98 & 97 & 16 & 11 \\
\hline $56 \mathrm{PU}+168 \mathrm{U}$ & 8 Sept. & 7 Sept. & 98 & 97 & 20 & 20 \\
\hline $0 \mathrm{PU}+224 \mathrm{U}$ & 31 Aug. & 2 Sept. & 97 & 97 & 17 & 15 \\
\hline $168 \mathrm{PU}+0 \mathrm{U}$ & 3 Sept. & 2 Sept. & 98 & 98 & 18 & 11 \\
\hline $0 \mathrm{PU}+168 \mathrm{U}$ & 8 Sept. & 7 Sept. & 99 & 98 & 17 & 14 \\
\hline $112 \mathrm{PU}+0 \mathrm{U}$ & 8 Sept. & $7 \mathrm{Sept}$. & 98 & 98 & 25 & 10 \\
\hline $0 \mathrm{PU}+112 \mathrm{U}$ & 3 Sept. & 2 Sept. & 98 & 97 & 20 & 15 \\
\hline $\mathrm{LSD}_{0.05}$ & NS & NS & NS & NS & 10 & 15 \\
\hline
\end{tabular}

NsNonsignificant.

Table 4. Effect of rates of urea (U) and polymer-coated urea (PU) on dry weight (DW) and leaf area (LA) for different dates during the 1998 growing season. Dry weight and leaf area were $0.5 \mathrm{~g}$ and $150 \mathrm{~cm}^{2}$, respectively, on 27 May 1998, when $\mathrm{N}$ treatments were applied. Treatments equal to the total amount of nitrogen supplied from the different nitrogen sources.

\begin{tabular}{|c|c|c|c|c|c|c|}
\hline \multirow{2}{*}{$\begin{array}{l}\text { Treatment } \\
\left(\mathrm{kg} \cdot \mathrm{ha}^{-1} \mathrm{~N}\right)\end{array}$} & \multicolumn{2}{|c|}{24 June } & \multicolumn{2}{|c|}{28 July } & \multicolumn{2}{|c|}{24 Aug. } \\
\hline & DW $(g)$ & $\mathrm{LA}\left(\mathrm{cm}^{2}\right)$ & $\mathrm{DW}(\mathrm{g})$ & $\mathrm{LA}\left(\mathrm{cm}^{2}\right)$ & DW $(g)$ & $\mathrm{LA}\left(\mathrm{cm}^{2}\right)$ \\
\hline $224 \mathrm{PU}+0 \mathrm{U}$ & 3.23 & 1334 & 20.13 & 14694 & 33.64 & 14690 \\
\hline $168 \mathrm{PU}+56 \mathrm{U}$ & 2.93 & 993 & 17.33 & 14898 & 30.70 & 15539 \\
\hline $112 \mathrm{PU}+112 \mathrm{U}$ & 2.08 & 958 & 19.22 & 14910 & 27.70 & 14701 \\
\hline $56 \mathrm{PU}+168 \mathrm{U}$ & 2.47 & 810 & 17.12 & 10999 & 25.09 & 16383 \\
\hline $0 \mathrm{PU}+224 \mathrm{U}$ & 2.37 & 988 & 17.98 & 13943 & 24.48 & 12923 \\
\hline $168 \mathrm{PU}+0 \mathrm{U}$ & 2.87 & 1169 & 22.31 & 15065 & 30.64 & 15651 \\
\hline $0 \mathrm{PU}+168 \mathrm{U}$ & 2.41 & 1164 & 19.04 & 13860 & 29.68 & 17912 \\
\hline $112 \mathrm{PU}+0 \mathrm{U}$ & 2.33 & 1153 & 21.3 & 12422 & 29.22 & 14389 \\
\hline $0 \mathrm{PU}+112 \mathrm{U}$ & 3.04 & 996 & 20.04 & 16088 & 24.47 & 13103 \\
\hline $\mathrm{LSD}_{0.05}$ & 0.9 & 250 & 4.1 & 908 & 8.6 & 3157 \\
\hline
\end{tabular}

to improve storage compared with plants supplied with urea-N. Excessive and low N application rates have been reported by others to delay bulb maturity (Henriksen, 1987; Schwartz and Bartolo, 1995) and adversely affect storability (Brewster, 1994; Brown et al., 1988).

While N rate and formulation significantly impacted yield, effects on plant growth in both years were less noticeable. Leaf area increased until the end of July but changed little during August (Table 4). Application of N at 224 $\mathrm{kg} \cdot \mathrm{ha}^{-1}$ as PU increased dry weight and leaf area compared with urea applied at the same rate. In addition, as the proportion of urea in the fertilizer mix increased, the dry weight and leaf area tended to decrease. Reducing the $\mathrm{N}$ rate from 224 to $112 \mathrm{~kg} \cdot \mathrm{ha}^{-1}$ had little effect on dry weight or leaf area. Dry weight continued to increase throughout the year. Onion growth followed accepted patterns of development, with rapid leaf development until midseason followed by a cessation of leaf development as the bulb enlarged (Brewster, 1994).

Soil nitrogen. Cross-sectional soil sampling in early Aug. 1999 indicated significant positional variability in $\mathrm{NO}_{3}-\mathrm{N}$ across the onion beds in selected PU and urea-treated soils (Figs. 2 and 3). More $\mathrm{NO}_{3}-\mathrm{N}$ was confined to a zone of soil in the center of the bed for the PU treatment compared with the urea treatment. The low concentrations of $\mathrm{NO}_{3}-\mathrm{N}$ in the ureatreated soil were apparently due to leaching losses associated with furrow irrigation. Higher $\mathrm{NO}_{3}-\mathrm{N}$ levels with $\mathrm{PU}$ could be explained by the controlled-release characteristics of the polymer, which minimized leaching loss. Brown et al. (1988) reported that preplant urea applications concentrated nitrate levels in onion beds more than sulfur-coated urea. They attributed the slower release of $\mathrm{N}$ to the sulfurcoated urea, which improved plant uptake and use.

The monthly soil samples collected in the 
bed centers were sufficiently variable each year that no significant difference in soil $\mathrm{NO}_{3}$ $\mathrm{N}$ concentrations was detected between treatments (Table 5). There were, however, significant differences in $\mathrm{NO}_{3}-\mathrm{N}$ between replicates. This variability was due in part to the use of furrow irrigation, only collecting a single soil sample from the bed center, and the layout of the experiment design. Replicates near the top end of the field generally had higher $\mathrm{NO}_{3}-\mathrm{N}$ levels than those near the tail end. Water ponding and backup of the irrigation stream would contribute to excessive N leaching near the lower end of the field.

$\mathrm{N}$-use efficiency. Leaf $\mathrm{N}$ tended to increase until early August, then decrease as plants matured or as leaching of $\mathrm{N}$ occurred in the furrow-irrigated onions. Application of different combinations of PU and urea had variable effects on leaf $\mathrm{N}$ concentrations in both years of the study (data not shown). No distinct tissue $\mathrm{N}$ patterns were detected when single-degree-of-freedom contrasts were used to test for treatment differences (data not shown). Patterns were not detected due to variability between the samples in 1998 and the high pre-fertilization concentrations of soil $\mathrm{N}$ in 1999, which elevated tissue levels in all treatments. Brownet al. (1988) and Wiedenfeld (1986) also reported variable tissue $\mathrm{N}$ concentrations when comparing slow-release with urea $\mathrm{N}$ fertilizers.

Nitrogen use efficiency decreased linearly $\left(\mathrm{y}=0.78-0.002 \mathrm{x} ; r^{2}=0.92\right)$ as more urea was introduced into the fertilizer mix (Table 6). This effect was due primarily to a reduction in NUPE as the proportion of urea in the mix increased and reflects the $\mathrm{N}$ leaching losses that occurred with soluble $\mathrm{N}$ fertilizers. Nitrogen use efficiency tended to be greater in those treatments receiving less $\mathrm{N}$ either as urea or PU. These improvements in NUE reflect greater capture and use of $\mathrm{N}$ for growth, though overall yield was reduced by $\mathrm{N}$ limitations. Single-degree-of-freedom comparisons (not shown) of the different forms of $\mathrm{N}$ applied at the same rate (224PU vs. $224 \mathrm{U}$; $168 \mathrm{PU}$ vs. $168 \mathrm{U} ; 112 \mathrm{PU}$ vs. 112U) showed that in all cases application of PU improved NUE compared with urea. We noted similar trends in NUPE and NUTE in 1999 although overall NUE was lower due to the high fall application of $\mathrm{N}$ by the grower (data not shown).

\section{Conclusions}

Results from this study suggest that the use of PU is beneficial for onion production. Use of PU by growers will depend on ease of application, cost of the product, nutrient savings, and projected crop returns. Since onion yields with a $168 \mathrm{PU}+56 \mathrm{U}$ mix were comparable with that of 224PU, blends of these materials may be a way to encourage PU use at a reduced cost to the producer. The yield increase associated with using 224PU compared with $168 \mathrm{PU}+56 \mathrm{U}$ might offset the additional cost of the controlled-release $\mathrm{N}$ source. A detailed cost-benefit analysis is needed to determine the feasibility of using the more expensive PU sources.

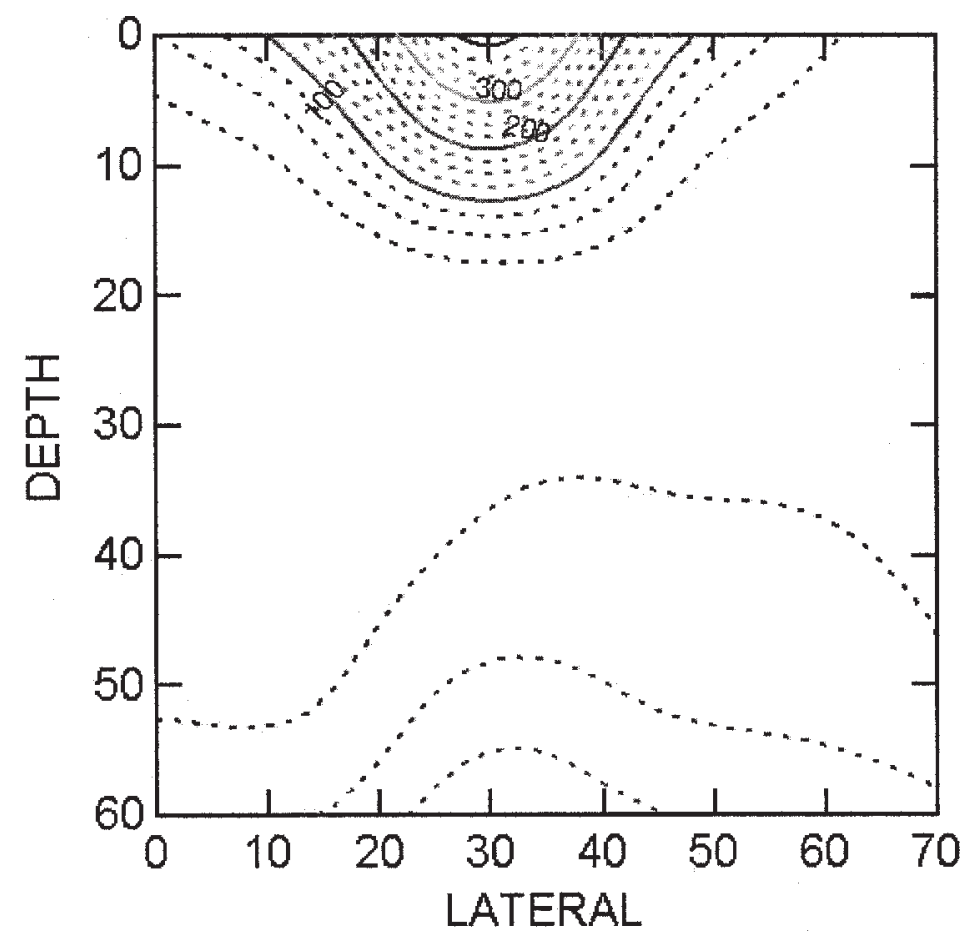

Fig. 2. Spatial distribution of $\mathrm{NO}_{3}-\mathrm{N}$ in early Aug. 1999 across an onion bed treated with a polymer-coated urea at $224 \mathrm{~kg} \cdot \mathrm{ha} \mathrm{a}^{-1} \mathrm{~N}$. Data expressed as milligrams of $\mathrm{NO}_{3}-\mathrm{N}$ per kilogram of soil in two dimensions.

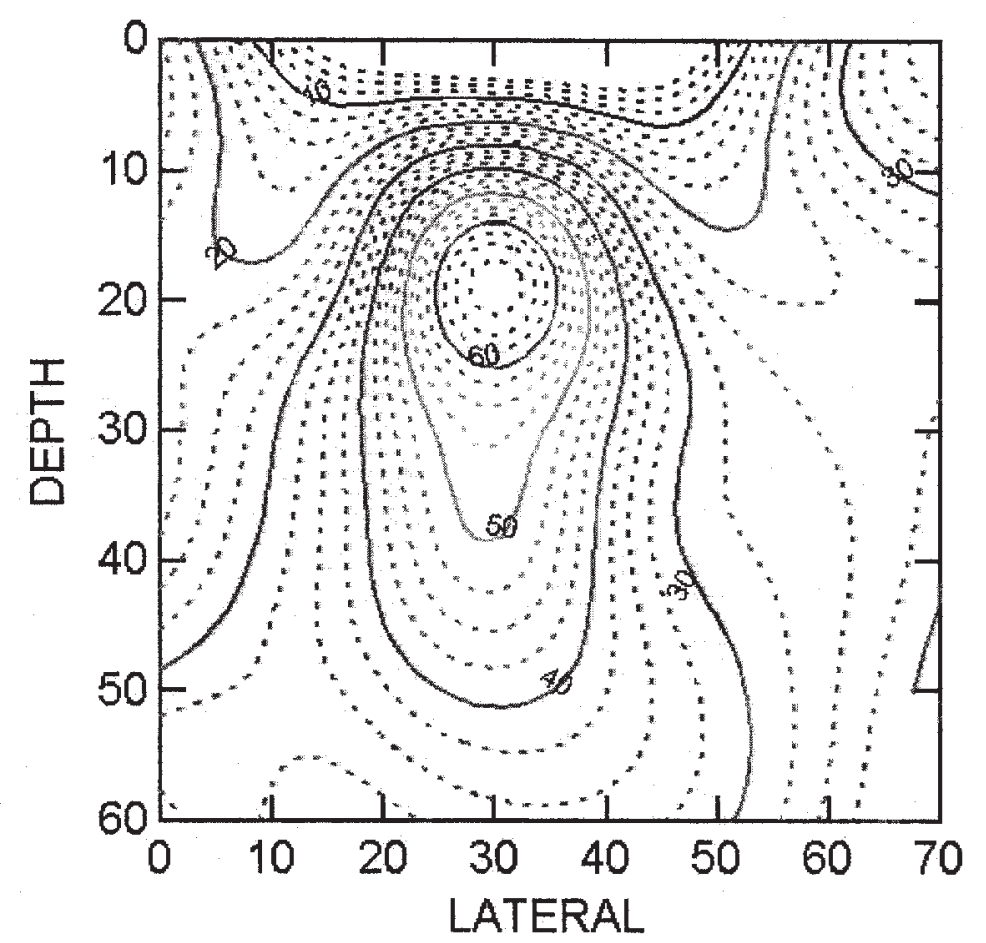

Fig. 3. Spatial distribution of $\mathrm{NO}_{3}-\mathrm{N}$ in early Aug. 1999 across an onion bed fertilized with urea at 224 $\mathrm{kg} \cdot \mathrm{ha}^{-1} \mathrm{~N}$. Data expressed as milligrams of $\mathrm{NO}_{3}-\mathrm{N}$ per kilogram of soil in two dimensions. 
Table 5. Effect of rates of urea (U) and polymercoated urea (PU) on soil nitrate (milligrams $\mathrm{NO}_{3}-\mathrm{N}$ per kilogram) concentration for three sampling dates during 1999. Treatments equal to the total amount of nitrogen supplied from the different nitrogen sources.

\begin{tabular}{lccc}
\hline $\begin{array}{l}\text { Treatment } \\
\left(\mathrm{kg} \cdot \mathrm{ha}^{-1} \mathrm{~N}\right)\end{array}$ & July & August & September \\
\hline $224 \mathrm{PU}+0 \mathrm{U}$ & 43.7 & 27.0 & 24.1 \\
$168 \mathrm{PU}+56 \mathrm{U}$ & 36.5 & 28.7 & 20.8 \\
$112 \mathrm{PU}+112 \mathrm{U}$ & 30.3 & 26.8 & 31.6 \\
$56 \mathrm{PU}+168 \mathrm{U}$ & 42.2 & 25.3 & 25.7 \\
OPU + 224U & 37.2 & 27.3 & 21.6 \\
$168 \mathrm{PU}+0 \mathrm{U}$ & 28.6 & 23.3 & 17.4 \\
$0 \mathrm{PU}+168 \mathrm{U}$ & 31.4 & 29.1 & 20.7 \\
$112 \mathrm{PU}+0 \mathrm{U}$ & 29.7 & 21.0 & 24.4 \\
$0 \mathrm{PU}+112 \mathrm{U}$ & 46.2 & 26.3 & 21.6 \\
\hline LSD $_{0.05}$ & NS & NS & NS
\end{tabular}

Ns Nonsignificant.

Residual soil $\mathrm{NO}_{3}-\mathrm{N}$ values caused by the grower's individual $\mathrm{N}$ management practices confounded the study results in 1999 and may have masked any treatment effects on soil $\mathrm{NO}_{3}-\mathrm{N}$ amounts and distributions, and lowered NUE. Preseason soil sampling for $\mathrm{N}$ and correlating this information to onion yields would be useful. Soil N testing, which has been successful with other crops, could lead to lower $\mathrm{N}$ application rates, reduce the potential for $\mathrm{N}$ leaching, and improve crop profitability.

\section{Literature Cited}

Brewster, J.L. 1994. Onions and other vegetable Alliums. CAB Intl., Wallingford, U.K.

Brown, B. 2000. Southern Idaho fertilizer guide: Onions. Univ. of Idaho Current Info. Ser. No. 1081.
Table 6. Changes in nitrogen uptake efficiency (NUPE), nitrogen utilization efficiency (NUTE), and nitrogen use efficiency (NUE) in 1998 as affected by polymer-coated (PU)/urea (U) additions to onions. Treatments equal to the total amount of nitrogen supplied from the different nitrogen sources.

\begin{tabular}{lccc}
\hline \hline $\begin{array}{l}\text { Treatment } \\
\left(\mathrm{kg} \cdot \mathrm{ha}^{-1} \mathrm{~N}\right)\end{array}$ & $\begin{array}{c}\mathrm{NUPE}^{z} \\
\text { 1 Sept. }\end{array}$ & $\begin{array}{r}\mathrm{NUTE}^{\mathrm{y}} \\
\text { 1 Sept. }\end{array}$ & $\begin{array}{r}\mathrm{NUE}^{\mathrm{x}} \\
1 \text { Sept. }\end{array}$ \\
\hline $224 \mathrm{PU}+0 \mathrm{U}$ & 1.236 & 0.63 & 0.78 \\
$168 \mathrm{PU}+56 \mathrm{U}$ & 1.408 & 0.51 & 0.72 \\
$112 \mathrm{PU}+112 \mathrm{U}$ & 1.293 & 0.54 & 0.70 \\
$56 \mathrm{PU}+168 \mathrm{U}$ & 0.841 & 0.70 & 0.59 \\
0PU + 224U & 0.953 & 0.62 & 0.59 \\
$168 \mathrm{PU}+0 \mathrm{U}$ & 1.412 & 0.56 & 0.79 \\
0PU + 168U & 1.088 & 0.62 & 0.67 \\
$112 \mathrm{PU}+0 \mathrm{U}$ & 1.245 & 0.80 & 0.99 \\
0PU + 112U & 1.394 & 0.64 & 0.89
\end{tabular}

${ }^{\text {z NUPE }}=($ plant dry weight $\times$ population $\times$ tissue $\mathrm{N})$ total $\mathrm{N}$ applied.

${ }^{\mathrm{y}} \mathrm{NUTE}=$ Harvested yield $/($ plant dry weight $\times$ population $\times$ tissue $\mathrm{N}$ )

${ }^{x} \mathrm{NUE}=\mathrm{NUPE} \times \mathrm{NUTE}$.

Brown, B.D., A.J. Hornbacher, and D.V. Naylor. 1988. Sulfur-coated urea as a slow-release nitrogen source for onions. J. Amer. Soc. Hort. Sci. 113:864-869.

Drost, D., P. Grossl, and R. Koenig. 1997. Nutrient management of onions: A Utah perspective. Proc. Western Nutrient Mgt. Conf. 2:54-59.

Ells, J.E., A.E. McSay, P.N. Soltanpour, F.C. Schweissing, M.E. Bartolo, and E.G. Kruse. 1993. Onion irrigation and nitrogen leaching in the Arkansas Valley of Colorado, 1990-1991. HortTechnology 3:184-187.

Feibert, E., C. Shock, and M. Sanders. 1993. A comparison of sprinkler, subsurface drip and furrow irrigation of onions. Malheur County Crop Res. Rpt. No. 936. Oregon State Univ., Corvallis.
Guertal, E. 2000. Preplant slow-release nitrogen fertilizers produce similar bell pepper yields as split applications of soluble fertilizer. Agron. J. 92:388-393.

Hauck, R.D. 1985. Slow-release and bioinhibitoramended nitrogen fertilizers, p. 293-322. In: O.P. Englestad (ed.). Fertilizer technology and use. 3rd ed. SSSA. Madison, Wis.

Henriksen, K. 1987. Effect on N- and P-fertilization on yields and harvest time in bulb onions $(\mathrm{Al}$ lium cepa L.). Acta Hort. 208:207-215.

Hummel, N.W., Jr. 1989. Resin-coated urea evaluations for turfgrass fertilization. Agron. J. 81:290-294.

Kochba, M., S. Gambash, and Y. Avnimelech. 1990. Studies on slow release fertilizers: 1. Effects of temperature, soil moisture and water vapor pressure. Soil Sci. 149(6):339-343.

Mansour, N.S., J. Burr, H.J. Mack, E.H. Gardner, and T. Doerge. 1983. Fertilizer guide: OnionsMineral soils. Oregon State Univ. Ext. Serv., Corvallis.

Riekels, J.W. 1977. Nitrogen-water relationships of onions grown on organic soil. J. Amer. Soc. Hort. Sci. 102:139-142.

SAS Institute. 1997. SAS for Windows v. SAS 6.12. SAS Inst., Cary, N.C.

Scully, N.J., M.W. Parker, and H.A. Borthwick. 1945. Interaction of nitrogen nutrition and photoperiod as expressed in bulbing and flowerstalk development of onion. Bot. Gaz. 107:5261.

Schwartz, H.F. and M.E. Bartolo. 1995. Colorado onion production and integrated pest management. Ext. Bul. 547A. Colorado State Univ., Fort Collins.

Wang, F.L. and A.K. Alva. 1996. Leaching of nitrogen from slow-release urea sources in sandy soils. Soil Sci. Soc. Amer. J. 60:1454-1458.

Wiedenfeld, R.P. 1986. Rate, timing, and slowrelease nitrogen fertilizers on cabbage and onions. HortScience 21:236-238. 